\title{
Haematological abnormalities in acute pancreatitis. A prospective study
}

\author{
DESMOND MURPHY \\ M.B., Ch.B., M.R.C.P. \\ Clement W. IMrie* \\ B.Sc., F.R.C.S. \\ JOHN F. DAVIDSON $\dagger$ \\ M.B., F.R.C.P. \\ Centre for Respiratory Investigation, *University Department of Surgery, and $\dagger$ Department of \\ Haematology, Royal Infirmary, Glasgow
}

\begin{abstract}
Summary
Twenty-five patients with acute pancreatitis were studied prospectively in the first week of their admission using haematological and coagulation tests. Platelet counts initially fell and later returned to admission levels. Rising levels of plasma fibrinogen were recorded. The kaolin cephalin clotting time was shorter than its control in twenty-one patients. Eighteen patients had elevated fibrinogen degradation products and fourteen had a positive ethanol gelation test. It is suggested that by taking into account the results in series of individual patients a degree of intravascular coagulation may be a common feature of acute pancreatitis. In one patient (presented in detail) strong evidence for disseminated intravascular coagulation was found.
\end{abstract}

\section{Introduction}

Haematological abnormalities including coagulation upsets have been noted in patients with acute pancreatitis. Trapnell (1966) reported falls in serial values of haemoglobin, white blood count and haematocrit in patients admitted with acute pancreatitis. Innerfield, Angrist and Benjamin (1952) noted a state of hypocoagulability, whereas other workers have observed a hypercoagulable state (Shinowara et al., 1963; Hirayama et al., 1974). Disseminated intravascular coagulation (DIC) has been reported in acute pancreatitis (Minna, Robboy and Colman, 1974; Yoshikawa, Tanaka and Guze, 1971) and post-mortem studies confirm the presence of widespread thrombosis in a proportion of cases (Smyth, 1940).

No previous prospective study has been made of haematological and coagulation indices in patients with acute pancreatitis. In this study these indices have been examined prospectively, and an attempt has been made to assess the presence or absence of intravascular coagulation.

Correspondence: Dr D. Murphy, Senior Registrar, Radcliffe Infirmary, Oxford.
Materials and methods

The twenty-five patients with acute pancreatitis included in this study comprised fourteen male and eleven female patients with a mean age of 43 years. The criteria for diagnosis and the conservative management regimen for acute pancreatitis have been previously fully described (Imrie and Whyte, 1975). The aetiology of acute pancreatitis was attributed to excess alcohol intake in $48 \%$, biliary disease in $48 \%$ and in $4 \%$ no aetiological factor was identified (Table 1). There were no deaths in the study group.

TABLE 1. Aetiology, sex incidence, and age groups of the patients

\begin{tabular}{lcccc}
\hline & Alcohol & Biliary & Idiopathic & $\begin{array}{l}\text { Whole } \\
\text { group }\end{array}$ \\
\hline $\begin{array}{l}\text { Sex incidence } \\
\text { female: male }\end{array}$ & $1: 11$ & $10: 2$ & $0: 1$ & $11: 14$ \\
Mean age & 31 & 52 & 69 & 43 \\
\hline
\end{tabular}

The daily haematological and coagulation indices which were studied are listed in Table 2. Results are presented according to calendar days after admission. For this purpose, results belonging to day 0 are those obtained up to midnight on the day of admission, results belonging to day 1 indicate those obtained for the following $24 \mathrm{hr}$, and so on. Plasma fibrinogen was measured by the technique described by Clauss (1957), and serum fibrinogen degradation products by the method of Merskey, Kleiner and Johnson (1966) using the Wellcome FDP Kit. The ethanol gelation test as described by Godal and Abildgaard (1966), measures the level of soluble fibrin in the plasma. All other estimations were carried out using techniques described by Dacie and Lewis (1975). The kaolin cephalin clotting time (KCCT) is a sensitive test for minor defects of coagulation and is not affected by the platelet count. Results more than $6 \mathrm{sec}$ shorter or longer than a control were regarded as significant. 
TABLE 2. Investigations performed each day

\begin{tabular}{ll}
\hline Haemoglobin $(\mathrm{g} / \mathrm{dl})$ & One-stage prothrombin time \\
Haematocrit $(\%)$ & Kaolin cephalin clotting time \\
White blood count $\left(\right.$ cells $\left.\times 10^{9} / 1\right)$ & Thrombin time \\
Platelet count $\left(\right.$ cells $\left.\times 10^{9} / \mathrm{l}\right)$ & Plasma fibrinogen $(\mathrm{g} / \mathrm{l})$ \\
Reticulocyte count $(\%)$ & Fibrinogen degradation products $(\mu \mathrm{g} / \mathrm{ml})$ \\
Blood film & Ethanol gelation test
\end{tabular}

TABLE 3. Mean results daily with 1 s.d. for haemoglobin $(\mathrm{g} / \mathrm{dl})$, haemotocrit $(\%)$ white blood count (cells $\left.\times 10^{\circ} / 1\right)$, platelet count (cells $\left.\times 10^{\%} / \mathrm{l}\right)$, reticulocyte count $(\%)$, fibrinogen degradation products (FDPs) $(\mu \mathrm{g} / \mathrm{ml})$ and plasma fibrinogen (g/l). Follow-up results are on twenty-four patients

\begin{tabular}{|c|c|c|c|c|c|c|c|c|}
\hline & \multicolumn{7}{|c|}{ Day } & \multirow[b]{2}{*}{$\begin{array}{c}\text { Follow-up } \\
\text { Mean }( \pm \text { s.d. })\end{array}$} \\
\hline & $\begin{array}{c}0 \\
\operatorname{Mean}( \pm \text { s.d. })\end{array}$ & $\stackrel{1}{\operatorname{Mean}( \pm \text { s.d. })}$ & $\stackrel{2}{\operatorname{Mean}( \pm \text { s.d. })}$ & $\stackrel{3}{\operatorname{Mean}( \pm \text { s.d. })}$ & $\stackrel{4}{\operatorname{Mean}( \pm \text { s.d. })}$ & $\stackrel{5}{\operatorname{Mean}( \pm \text { s.d. })}$ & $\stackrel{6}{\operatorname{Mean}( \pm \text { s.d. })}$ & \\
\hline $\begin{array}{l}\text { Haemo- } \\
\text { globulin }\end{array}$ & $14.9(1.8)$ & $14.5(1.9)$ & $13 \cdot 6(1 \cdot 7)$ & $13 \cdot 4(1 \cdot 3)$ & $12 \cdot 7(1 \cdot 9)$ & $12 \cdot 7(1 \cdot 5)$ & $12 \cdot 5(1 \cdot 2)$ & $13 \cdot 7(1 \cdot 3)$ \\
\hline Haemotocrit & $42 \cdot 9(5 \cdot 1)$ & $42 \cdot 3(5 \cdot 5)$ & $39 \cdot 9(5 \cdot 1)$ & $38.8(3 \cdot 7)$ & $36.9(5 \cdot 1)$ & $36 \cdot 8(4 \cdot 2)$ & $36 \cdot 2(3 \cdot 3)$ & $40 \cdot 4(3 \cdot 8)$ \\
\hline $\begin{array}{l}\text { White blood } \\
\text { count }\end{array}$ & $14 \cdot 7(4 \cdot 6)$ & $12 \cdot 9(5 \cdot 0)$ & $11 \cdot 2(4 \cdot 4)$ & $9.9(4 \cdot 4)$ & $9.0(3.6)$ & $8.9(3.4)$ & $8.9(2 \cdot 4)$ & $6 \cdot 6(1 \cdot 6)$ \\
\hline Platelet count & $306 \cdot 0(79 \cdot 0)$ & $235 \cdot 0(79 \cdot 0)$ & $205 \cdot 0(71 \cdot 0)$ & $230.0(55.0)$ & $282 \cdot 0(110.0)$ & $265 \cdot 0(98 \cdot 0)$ & $298 \cdot 0(92 \cdot 0)$ & $234 \cdot 0(68 \cdot 0)$ \\
\hline $\begin{array}{l}\text { Reticulocyte } \\
\text { count }\end{array}$ & $3 \cdot 6(3 \cdot 0)$ & $1.72(0.9)$ & $1.81(0.9)$ & $1.94(1.6)$ & $2 \cdot 0(1 \cdot 5)$ & $1.62(0.6)$ & $2 \cdot 11(1 \cdot 5)$ & $1 \cdot 76\left(2 \cdot 3^{*}\right)$ \\
\hline FDPs & $12 \cdot 75(15 \cdot 8)$ & $22 \cdot 3(35 \cdot 6)$ & $19 \cdot 01(33 \cdot 3)$ & $20 \cdot 13(36 \cdot 4)$ & $14.79(18.8)$ & $19 \cdot 47(40 \cdot 7)$ & $12.80(15.4)$ & $1.86\left(1 \cdot 3^{*}\right)$ \\
\hline $\begin{array}{l}\text { Plasma } \\
\text { fibrinogen }\end{array}$ & $2 \cdot 22(0 \cdot 3)$ & $3 \cdot 71(1 \cdot 2)$ & $4 \cdot 67(1.9)$ & $5 \cdot 86(1 \cdot 5)$ & $5 \cdot 76(1.8)$ & $5 \cdot 14(1 \cdot 7)$ & $5 \cdot 18(1 \cdot 7)$ & $2 \cdot 43(0 \cdot 7)$ \\
\hline
\end{tabular}

* Only twenty-three results.

\section{Results}

The results are summarized in Table 3. Monitoring of haematological indices revealed a downward trend in the mean value of haemoglobin, haematocrit and white blood count (WBC). The haemoglobin fell below normal values in twelve $(48 \%)$ and the haematocrit in twenty-two $(88 \%)$ patients. The mean WBC on admission was $14.6 \times 10^{9} / 1\left(14,600 / \mathrm{mm}^{3}\right)$ and $64 \%$ of patients exhibited a leucocytosis at some point in the first week of their illness. Slight anisocytosis was recorded in the blood films of sixteen patients, rouleaux formation noted in seven, and polychromasia in three. Although there was a considerable range of values for the platelet count, the overall tendency was for a falling level to be recorded for the initial $72 \mathrm{hr}$ of admission with slow recovery thereafter (Fig. 1). Five patients had an elevated platelet count of $>400 \times 10^{9} / 1\left(400,000 / \mathrm{mm}^{3}\right)$, but in none of these did this occur in the initial $72 \mathrm{hr}$ of illness. Marked fluctuations were recorded in the reticulocyte count between $1 \%$ and $7 \%$ and elevation was noted at least on one occasion in fifteen patients. There was slight prolongation of prothrombin time in only one patient ( $5 \mathrm{sec}$ greater than control) and no significant abnormality in the thrombin time. KCCT was shorter than its control in twenty-one $(84 \%)$ patients and in eight $(32 \%)$ by greater than 6 sec. Only one patient exhibited a significant prolongation (more than $6 \mathrm{sec}$ ) compared to control.

Serum fibrinogen degradation product results (FDPs) are shown in Table 4 and Fig. 1 demonstrating elevated mean values for the group as a whole. The majority of patients $(75 \%)$ had elevated serum FDP levels at some stage in the period of study and the highest level recorded was $160 \mu \mathrm{g} / \mathrm{ml}$ in two patients.

TABLE 4. Fibrinogen degradation products (FDPs)

\begin{tabular}{cc}
\hline $\begin{array}{l}\text { No. of } \\
\text { patients }\end{array}$ & $\begin{array}{c}\text { FDPs } \\
(\mu \mathrm{g} / \mathrm{ml})\end{array}$ \\
\hline 3 & $>40$ \\
15 & $5-40$ \\
6 & $0-5$ \\
1 & No result \\
Total 25 & \\
\hline
\end{tabular}

Fibrinogen levels, which were in the normal range on admission, rose steadily and the mean values were persistently elevated from day 2 onward (Fig. 1).

The ethanol gelation test (EGT) was positive in $56 \%$ of patients.

Aetiology did not appear to affect the haematological and coagulation indices examined as there 

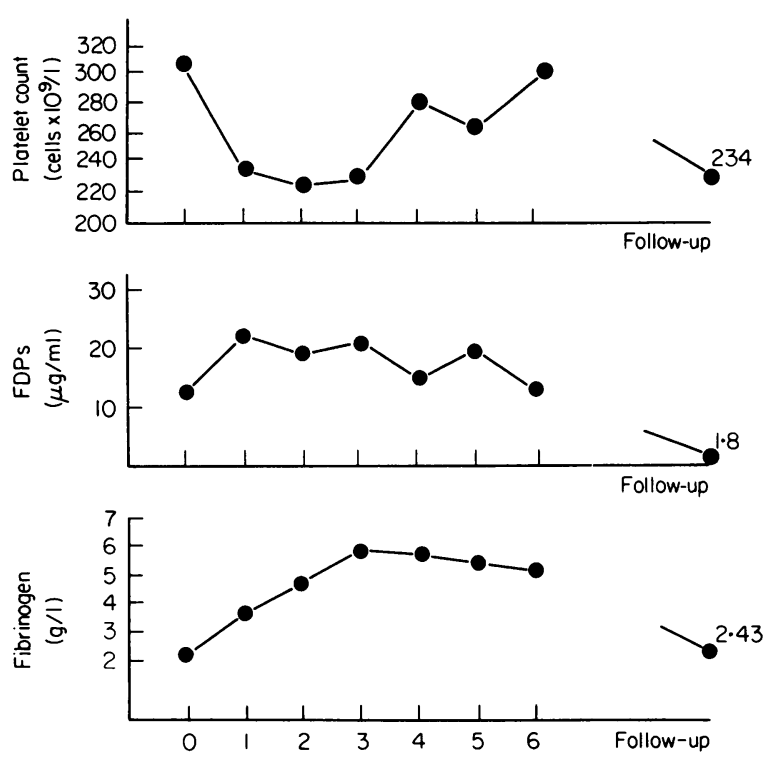

FIG. 1. Mean results depicted graphically for platelet count, FDPs $(\mu \mathrm{g} / \mathrm{ml})$, and plasma fibrinogen. Follow-up results on twenty-four patients.

was no significant difference between the results obtained in the patients with biliary disease and those with alcohol associated pancreatitis.

In one patient (described below) clinical and haematological evidence of DIC was found.

\section{Case history}

A 29-year-old male patient with alcohol associated pancreatitis was admitted as an emergency and treated with the standard conservative management regime (Imrie and Whyte, 1975). His initial haemoglobin was $14.3 \mathrm{~g} / \mathrm{dl}$, platelet count $178 \times 10^{9} / 1$ $\left(178,000 / \mathrm{mm}^{3}\right)$, and the serum FDP value on three occasions was $160 \mu \mathrm{g} / \mathrm{ml}$ (Fig. 2). The haemoglobin value progressively fell until day 4 when it was $7 \cdot 8 \mathrm{~g} / \mathrm{dl}$ and at this time the platelet count was less than $20 \times 10^{9} / 1\left(20,000 / \mathrm{mm}^{3}\right)$ while the serum FDP value had fallen from the markedly elevated value present in the initial $72 \mathrm{hr}$ of illness, to $40 \mu \mathrm{g} / \mathrm{ml}$. The reticulocyte count reached $5 \%$ and the blood film on five separate occasions showed red cell fragments and Burr cells. Icterus had been noted clinically after $48 \mathrm{hr}$ of admission and the serum bilirubin reached a peak of $88 \mu \mathrm{mol} / 1$ on day 2 , falling gradually to normal values by day 8 . Aspartate and alanine transaminases and alkaline phosphatase were not elevated during this time. There was no identifiable source of gastrointestinal blood loss and no evidence of para-umbilical or flank staining to suggest gross haemorrhagic pancreatitis. His general condition was satisfactory with a stable blood pressure of $125 /$

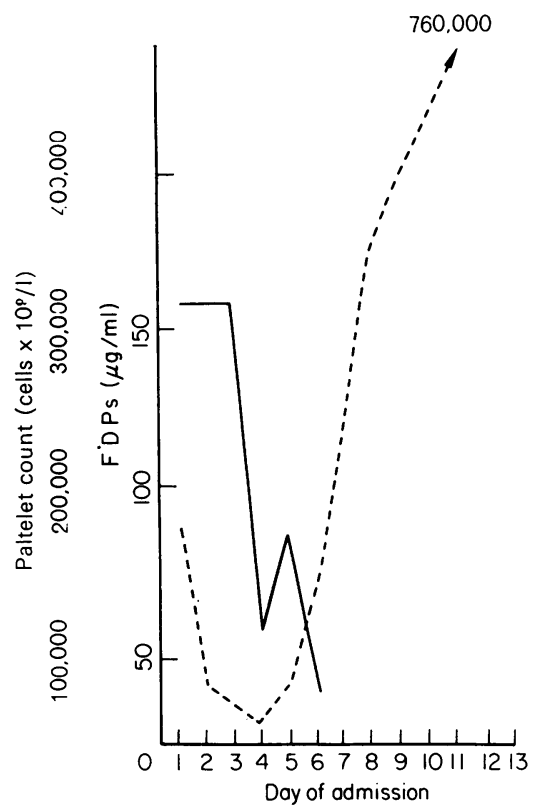

FIG. 2. Platelet count (- - ) and fibrinogen degradation products (-) for patient described in text.

$85 \mathrm{mmHg}$ and heart rate between 86 and 96 beats $/ \mathrm{min}$ (sinus rhythm). It was decided to withhold heparin therapy, and blood transfusion was carried out. Over the ensuing few days, his haemoglobin, platelet count and serum FDP levels returned to more normal values and there was no evidence of renal failure. Fibrinogen levels were elevated between 4 and $6 \mathrm{~g} / \mathrm{l}$ during the first week of illness. Despite the elevated plasma fibrinogen, disseminated intravascular coagulation remains the most reasonable explanation for all the recorded features in this patient.

Follow-up on twenty-four of the patients, a minimum period of 3 months after acute pancreatitis, has revealed results within or close to the normal range for routine indices, reticulocyte count, plasma fibrinogen and FDPs indicating the temporary nature of these changes (Table 5). KCCT was noted

TABLE 5. Follow-up results in study at least 3 months after acute pancreatitis in twenty-four return patients.

Haemoglobin

* Reticulocyte count

Blood film

One-stage prothrombin time

Kaolin cephalin clotting time

Thrombin time

Plasma fibrinogen

*Fibrinogen degradation products Ethanol gelation test
$<$ Normal in 2 $>$ Normal in 3 Anisocytosis in 6 Normal in all Shorter in 2 Normal in all $<$ Normal in 2 $>$ Normal in 2 Normal in all Positive in 7

\footnotetext{
* Only twenty-three results.
} 
to be shorter than the controls in eleven of the twenty-four patients, but in only two was this significant (more than $6 \mathrm{sec}$ ).

\section{Discussion}

The falling haemoglobin and haematocrit during the first week may be caused by a combination of the haemodilution, intravascular coagulation and blood loss into and around the pancreas, and has been noted previously (Trapnell, 1966). An early leucocytosis has also been recorded in patients with acute pancreatitis and has been associated with a more severe form of the disease (Ranson et al., 1974; Thal, Perry and Egner, 1957). Abnormal blood films and reticulocyte counts were of a minor nature but fragmentation and Burr cell formation was evident in the one patient described whose reticulocyte count reached $5 \%$.

Markedly elevated plasma fibrinogen levels, shortened KCCTs, elevated FDPs and positive EGTs are consistent with intravascular coagulation although they could be interpreted as a non-specific reaction to injury. A raised plasma fibrinogen and elevated FDPs have been noted previously in acute pancreatitis and these changes were attributed to a hypercoagulable state (Shinowara et al., 1963; Hirayama et al., 1974; Mungall and Hague, 1975). DIC with secondary fibrinolysis can cause FDP elevation (Yoshikawa et al., 1971; Merskey et al., 1966; Owen and Bowie, 1974) and this would also explain the positive EGT results (Gurewich, 1974; Kierulf and Godal, 1971). In those patients with acute pancreatitis in whom DIC has been described (Mungall and Hague, 1975; Kwaan, Anderson and Gramatica, 1971; Warshaw et al., 1974; Greipp, Brown and Gralnick, 1972) there were co-existing factors which could have been responsible for intravascular coagulation. None of these factors was present in the patient described.

Other possible explanations for elevated FDPs in patients with acute pancreatitis include obstructive jaundice, liver disease, pulmonary embolus and venous thrombosis (Merskey et al., 1966) or local haemorrhage (Malleson, 1974). The infrequency of severe thrombocytopenia in the study also suggests that widespread intravascular coagulation is not present but does not exclude local intravascular coagulation.

By generally accepted criteria (Minna et al., 1974) only one of the patients in this study manifested DIC. However the balance between hyper- and hypocoagulability (Owen and Bowie, 1974; Fedder, Prakke and Vreeken, 1972) and the time of blood sampling may explain the different results obtained by different workers (Innerfield et al., 1952; Shinowara et al., 1963; Hirayama et al., 1974).

The described sequential results for platelet count, fibrinogen, KCCT, ethanol gelation tests and serum FDPs in the present patients are consistent with a common hypercoagulable state in acute pancreatitis. This hypercoagulability may be associated with localized intravascular coagulation and in rarer instances disseminated intravascular coagulation may take place. It is important to note the normal findings for most coagulation indices at follow up. Gastric erosions, acute peptic ulceration and bleeding into the pancreatic tissues or a pseudo-cyst, are usually considered the major causes of a falling haemoglobin in patients with acute pancreatitis, but this additional cause must be kept in mind and appropriate investigations performed.

\section{References}

Clauss, A. (1957) Gerinnungsphysiologische Schnellmethode zur Bestimmung des Fibrinogens. Acta haematologica, 17, 237.

DACIE, J.V. \& Lewis, S.M. 1975. Practical Haematology, 5th Edn. Churchill, London.

Fedder, G., Prakke, E.M. \& Vreeken, J. (1972) On the early detection of intravascular coagulation. Thrombosis et diathesis haemorrhagica, 27, 365.

GodAL, H.C. \& ABILDGAARD, U. (1966) Gelation of soluble fibrin in plasma by ethanol. Scandinavian Journal of Haematology, 3, 342.

GreipP, P.R., Brown, J.A. \& Gralnick, H.R. (1972) Defibrination in acute pancreatitis. Annals of Internal Medicine, 76, 73.

GurEwiCH, V. (1974) Causes of a negative ethanol gelation test in diffuse intravascular coagulation. Thrombosis et diathesis haemorrhagica, 32, 243.

Hiravama, A., Uehara, S., Itagaki, Y., Izumiyama, S., Kudo, M. \& SATo, T. (1974) Coagulation study in pancreatitis. Japanese Journal of Clinical Haematology, 15, 171.

IMRIE, C.W. \& Whyte, A.S. (1975) A prospective study of acute pancreatitis. British Journal of Surgery, 6, 490.

InNerfield, I., Angrist, A. \& Benjamin, J.W. (1952) Antithrombin titer in acute pancreatitis. American Journal of Medicine, 12, 24.

Kierulf, P. \& Godal, H.C. (1971) Fibrinemia in medical patients screened by the ethanol test. Acta medica scanainavica, 190, 185.

Kwaan, H.C., Anderson, M.C. \& Gramatica, L. (1971) A study of pancreatic enzymes as a factor in the pathogenesis of disseminated intravascular coagulation during acute pancreatitis. Surgery, 69, 663.

Malleson, P.N. (1974) Abnormal coagulation and trauma. Lancet, ii, 1395.

Merskey, C., Kleiner, G.J. \& Johnson, A.J. (1966) Quantitative estimation of split products of fibrinogen in human serum, relation to diagnosis and treatment. Blood, 28,1 .

Minna, J.D., Robboy, S.J. \& Colman, R.W. (1974) Disseminated Intravascular Coagulation in Man, pp. 19-25, 27. Thomas, Springfield, Illinois.

Mungall, I.P.F. \& Hague, R.V. (1975) Pancreatitis and the pill. Postgraduate Medical Journal, 51, 855.

OWEN, C.A. \& BowIE, E.J.W. (1974) Chronic intravascular coagulation syndromes. Proceedings. Mayo Clinic, 49, 673.

Ranson, J.H.C., Rifkind, K.M., Roses, D.F., FinK, S.D., Eng, K. \& Spencer, F.C. (1974) Prognostic signs and the role of operative management in acute pancreatitis. Surgery, Gynecology and Obstetrics, 139, 69. 
Shinowara, G.Y., Stutman, L.J., Walters, M.I., Ruth, M.E. \& WALKER, E.J. (1963) Hypercoagulability in acute pancreatitis. American Journal of Surgery, 105, 714.

SмYTH, C.J. (1940) Etiology of acute hemorrhagic pancreatitis with special reference to vascular factors; analysis of autopsies and experimental investigation. Archives of Pathology, 30, 651 .

T'hal, A.P., Perry, J.F. \& Egner, W. (1957) A clinical and morphological study of forty-two cases of fatal acute pancreatitis. Surgery, Gynecology and Obstetrics, 105, 191.
TRAPNELL, J.E. (1966) The natural history and prognosis of acute pancreatitis. Annals of the Royal College of Surgeons of England, 38, 265.

Warshaw, A.L., Imbembo, A.L., Civetta, J.M. \& Daggett, W.M. (1974) Surgical intervention in acute necrotizing pancreatitis. American Journal of Surgery, 127, 484.

Yoshikawa, T., Tanaka, K.R. \& Guze, L.B. (1971) Infection and disseminated intravascular coagulation. Medicine, Baltimore, 50, 237. 